\title{
Characteristics of Bioethanol from Musa Salaccensis ZOLL
}

\author{
Dady Sulaiman ${ }^{1}$, St Syahdan ${ }^{2}$, Siti Maria Ulva ${ }^{3}$ \\ 1,2,3 Universitas Kaltara, Bulungan, Indonesia \\ Email: dadysulaiman@fmipa.unikaltar.ac.id
}

\begin{abstract}
The high increase in energy use causes renewable energy solutions such as wind energy, geothermal energy, biomass and others. Biomass is one solution for Indonesia to obtain energy, because Indonesia has the potential for biomass, both biodiesel and bioethanol. The biomass to be studied is Bioethanol. Forest banana is a type of wild plant that grows in the forests of North Kalimantan and is not consumed by residents because there are many seeds in the banana. The purpose of this study was to examine the characteristics of bioethanol from forest bananas. The stages of the research method that will be carried out include several stages, namely 1) making bioethanol, 2) measuring ethanol content, and 3 ) testing the characteristics of bioethanol. The stages of bioethanol testing carried out characteristic tests including: 1) Ethanol Content Analysis, 2) Moisture Content Analysis, 3) Density Analysis, 4) Specific Gravity and API Gravity Analysis, 5) Calorific Value Analysis. Based on the research results obtained, the quality of the bioethanol produced has a density value and specific gravity in accordance with the bioethanol quality standard, which is 0.46 . The calorific value which has a close relationship with API Gravity is close to the maximum value in the bioethanol quality standard, which is $3702.30 \mathrm{kcal} / \mathrm{kg}$. The value of ethanol content and water content still does not meet the quality standards, namely $24.8 \%$ and $86 \%$. This is due to the lack of distillation process in this study.
\end{abstract}

Keywords: Bioethanol, Musa Salaccensis ZOLL.

\section{A. INTRODUCTION}

Energy is a basic need in people's daily lives globally. Until now, there are various types of energy sources that can be used such as solar, geothermal, wind, biomass, natural gas, and other fossil fuels (Nugroho \& Subagyo, 2020). Almost all fields require energy to carry out their activities (Naimah \& Zen, 2021). ) such as agriculture which uses heavy equipment, industrial sector to manufacture its products en masse and various other fields. In addition, energy needs are also influenced by economic, building and population growth that continues to increase (Naimah \& Zen, 2021; Sulaiman et al., 2021).

Fossil fuels are the main fuels used by almost all fields. The use of fossil fuels will continue to increase by around 3\% per year (Naimah \& Zen, 2021; Alshammari et al, 2011). The high percentage of use of fossil fuels is inversely proportional to the level of production which is decreasing every year. In 2015-2016, there was a decline in production of 25.3\% (Agustina et al., 2021; Nurjanah \& Aznury, 2021; Roni et al., 2020) and an increase in prices (Price escalation) in every crisis that occurred (Wusnah et al, 2016). This has made several countries/agencies switch to using alternative energy sources or renewable energy (Adistia et al., 2020). 
Biomass is one of the alternative energy sources. Biomass is an energy source made from agricultural and industrial waste (Alshammari et al., 2011). Biomass can be in the form of biogas, biodiesel, bioethanol and so on (Nadia, 2013). The biomass to be studied is in the form of Bioethanol (Nugroho \& Subagyo, 2020). Bioethanol is ethanol produced from the fermentation of glucose (sugar) using yeast, especially Saccharomyces cerevisiae (Kurniati et al., 2021; Nugroho \& Subagyo, 2020; Marlina \& Hainun, 2020; Retno \& Nuri, 2011). The separation of bioethanol is then carried out by distillation (Khaidir, 2012). Bioethanol usually uses plant raw materials. These raw materials are grouped into three groups, namely sugary, cellulose fiber and containing starch (Wusnah et al., 2019; Amus et al., 2020; Nugroho \& Subagyo).

Forest banana (Musa Salaccensis ZOLL) is a type of wild plant that grows in the forests of North Kalimantan (Sulistyaningsih \& Wawo, 2011). This fruit is not consumed by residents because there are many seeds in the banana. Forest bananas are among the easiest and fastest types of plants to grow. This type of plant can grow anywhere, so it is very unfortunate if it is not used as well as possible. Because this type of forest banana can be used as an alternative energy fuel that is renewable and environmentally friendly by converting it into bioethanol.

This study aims to utilize forest bananas as an ingredient to produce renewable energy sources, namely bioethanol and examine the process of making bioethanol from kepok banana peels and analyze the bioethanol content produced by forest bananas. This research should be done to help local people take advantage of this forest banana. In addition, this research can help residents in the economic field.

\section{B. METHOD}

This type of research is an experimental research laboratory Banana Forest to determine the characteristics of bioethanol so that it can be used as an alternative energy source. The tools used in this study were 1 package of distillators, plastic basin, glass cup, $1000 \mathrm{ml}$ measuring cup, stove, scales, thermometer, and alcoholmeter. The ingredients used in this study were ice cubes, Forest Banana and Yeast.

Stages this research was carried out in several stages, namely the stage of making bioethanol, the stage of measuring bioethanol levels, and testing the characteristics of bioethanol.

1. Bioethanol Production Stage

a. Prepare raw materials for forest bananas that have been peeled clean.

b. Perform forest banana refining. At this stage, grinding is done using a glass without crushing the seeds.

c. Furthermore, it is fermented by adding a variation of yeast mass as much as $5 \%$ of the total banana pulp (the raw material used is $1 \mathrm{~kg}$ ) or 50 grams of yeast (Fitria \& Lindasari, 2021).

d. Close the fermentation container tightly so that it is not contaminated and the fermentation takes place anaerobically, which does not require air. The fermentation process lasts for 7 days and after that the banana pulp will turn into 3 layers, namely a layer in the form of protein deposits, and above 
it is water and ethanol.

e. Separating the ethanol solution with protein deposits by carrying out a filtering process. The result is an ethanol solution that still contains water ready to be processed to the next stage, namely the distillation process.

f. Carry out a distillation process to separate ethanol from the fermented solution by heating the solution by keeping the heating temperature at the boiling point of ethanol $780 \mathrm{C}$, so that the ethanol evaporates first and the evaporation is channeled into the pipe, condensed and back again into liquid ethanol.

2. Bioethanol Level Measurement Stage.

This stage is carried out by inserting bioethanol into a measuring cup or tube or bottle whose height is longer than the length of the alcohol meter. Then insert the alcohol meter rod into the measuring cup. The alcohol meter will sink and the water level will show how much alcohol is in the solution.

a. Bioethanol Characteristic Testing Phase

1) Bioethanol Moisture Analysis

In the bioethanol water content test, it is done by calculating the initial weight of the fermented product minus the final weight after being distilled divided by the initial weight. The formulation in calculating the water content, namely: Water content $(\%)=\frac{A-B}{A} \times 100 \%$

Information:

A = Initial Sample Weight (ml)

$\mathrm{B}=$ Final Sample Weight $(\mathrm{ml})$

2) Density Analysis

Density is the amount of a substance contained in a unit volume. Based on the bioethanol quality requirements from the National Standards Agency, the maximum density is $0.8215 \mathrm{gr} / \mathrm{ml}$. The density of bioethanol is obtained by dividing the mass of bioethanol by its volume. (Hanum et al., 2013). Where the mass of bioethanol is the mass difference between the empty pycnometer and the one containing bioethanol.

$D s=\frac{m b}{v b}$

Information:

Ds = Density of Bioethanol $(\mathrm{gr} / \mathrm{ml})$

$\mathrm{mb}=$ Mass of Bioethanol (gr)

$\mathrm{vb}=$ Bioethanol Volume $(\mathrm{ml})$

3) Specific Gravity Analysis and the Gravity API

Specific Gravity (sg) value is proportional to the density value, this value is the weight per unit volume of a material. The relationship between specific gravity (sg) and API gravity $(\mathrm{G})$ is as follows.

$G=\frac{141,5}{s g}-131,5$

The value of API Gravity ranges from $0-100$, while specific gravity is the relative price of the density of a material with respect to water. The 
values of density, Specific gravity and API gravity are then used to calculate the calorific value. The relationship between density and specific gravity is as follows:

$s g=\frac{\text { density }\left(\frac{\mathrm{kg}}{\mathrm{m}^{3}}\right)}{\text { density air }\left(\frac{\mathrm{kg}}{\mathrm{m}^{3}}\right)}$

Information:

$\mathrm{G}=$ Gravity API

$\mathrm{sg}=$ specific gravity

4) Calorific Value Analysis

This analysis aims to determine the heat energy produced in each bioethanol composition to be tested. Calorific value (NK) can be calculated using the following equation (Hanum et al., 2013).

$N K=\frac{2,2046226}{3,9673727} x(18,650+40 x(G-10) \mathrm{kkal} / \mathrm{kg})$

Information:

$\mathrm{NK}=$ Calorific Value $(\mathrm{kcal} / \mathrm{kg})$

$\mathrm{G}=$ API Gravity obtained from the calculation results in equation (2.3)

\section{RESULTS AND DISCUSSION}

The results of the research carried out in several stages including processing materials to prepare for fermentation, distillation and analyzing the characteristics of bioethanol. As well as testing the quality of bioethanol through a bioethanol characteristic test which includes analysis of water content, ethanol content, density, specific gravity and fire gravity, and calorific value.

The first step in the manufacture of bioethanol is to prepare raw materials for ripe bananas that have been peeled clean and then the bananas are mashed using a glass without crushing the seeds. Furthermore, fermentation is carried out by adding $5 \%$ yeast from the total banana pulp or from the total raw materials used (50 grams). The raw materials used in this study were $1 \mathrm{~kg}$ of forest bananas.

The fermentation process carried out in this study took 7 days. The fermentation process takes place anaerobically, which does not require air. The results of the fermentation will produce three layers, namely a layer in the form of protein deposits and above it is water and ethanol. Separating the ethanol solution from the protein precipitate was carried out by a filtering process. The ethanol solution which still contains water is ready to be processed to the next stage, namely the distillation process. The distillation process is carried out to separate ethanol from the fermented solution by heating the solution by maintaining the heating temperature at the ethanol boiling point of $78 \rrbracket^{\wedge} \mathrm{C}$ so that the ethanol first evaporates and the evaporation is channeled into the condensed pipe and returns to liquid ethanol. Continued to the stage of testing the characteristics of bioethanol to determine the quality of bioethanol made from forest bananas. The test results obtained data in Table 1 which was compared with bioethanol quality standards (Hanum et al., 2013). 
Table 1. Bioethanol Quality of Forest Bananas

\begin{tabular}{|l|c|c|c|}
\hline \multicolumn{1}{|c|}{ Quality Parameters } & $\begin{array}{c}\text { Bioethanol Quality } \\
\text { Standard }\end{array}$ & Results & Information \\
\hline Ethanol content (\%v/v) & Min 94.1 & 24,8 & Not appropriate \\
\hline Water content (\%) & Max 2 & 86 & Not appropriate \\
\hline Density (gr/ml) & Max 0.8215 & 0,46 & In accordance \\
\hline Specific Gravity & Max 0.8215 & 0,46 & In accordance \\
\hline Calorific Value (kkal/kg) & Max 5000 & 3702,30 & In accordance \\
\hline
\end{tabular}

Based on table 1, the ethanol content of bioethanol made from forest bananas is $24.8 \%$. This indicates a non-compliance with the recognized bioethanol standard, which is at least $94.1 \%$. This discrepancy is due to the lack of repetition of the distillation process. The distillation process carried out will affect the results of the ethanol content. Several studies carried out repeated distillation until it reached the appropriate ethanol content. The glucose level obtained is still too small because the distillation process is still simple and the fermentation process is not optimal. Glucose levels obtained in this study, one of which was also caused by the absence of nutrient provision to the decomposing bacteria so that they did not work optimally in converting glucose into bioethanol.

The water content test was carried out by calculating the initial weight of the fermented product minus the final weight after being distilled divided by the initial weight. The water content produced in this study was $86 \%$. The data generated from this study indicate that the value of the water content of bioethanol does not meet the quality requirements of bioethanol with a maximum value of $2 \%$. This is because the ethanol produced is still not pure because it is mixed with water. The distillation process carried out is conventional distillation, so that ethanol made from forest bananas with yeast variations still contains a lot of water. The higher the water content, the lower the heat of combustion (Feri, 2010).

Bioethanol quality requirements in the analysis of the maximum bioethanol density of $0.8215 \mathrm{gr} / \mathrm{ml}$. The density values produced in the study shown in Table 1 above meet the bioethanol quality requirements, namely $0.46 \mathrm{gr} / \mathrm{ml}$. The addition of $5 \%$ yeast has a close relationship with microbial activity which grows and reproduces more and more (Bestari, 2013). The greater the number of microbes, the greater the amount of carbohydrates that break down into alcohol. The greater the amount of alcohol, the lower the density of the bioethanol produced. This is due to the nature of the yeast that converts glucose into ethanol.

Based on Table 1, the results of the study show that the value of Specific Gravity (sg) shows where the results obtained are in accordance with the maximum bioethanol quality standard of 0.8215 set by the National Standard Agency (BSN). It can be seen that the value of Specific Gravity (sg) with the amount of yeast $5 \%$ of the raw material is 0.46 . The results of this study indicate that bioethanol from forest bananas has the same quality as bioethanol made from coconut sap (Wijaya, 2012). The value of the API Gravity analysis obtained is inversely proportional to the analysis of Specific 
Gravity (sg). The value of API Gravity has a very close relationship with the calorific value of bioethanol. This is because the calorific value is directly proportional to the API Gravity value. The greater the API Gravity value, the higher the calorific value will be (Wijaya, 2012). However, this is also influenced by the fermentation process that must be in accordance with the specified time so that there is no decrease in the glucose produced.

The calorific value obtained from the results of the study showed that the forest banana fruit material was close to the value of bioethanol quality requirements. Where the bioethanol quality standard set by the National Standards Agency (BSN) is at a maximum calorific value of $5000 \mathrm{kcal} / \mathrm{kg}$. Seen in the amount of yeast amounting to $5 \%$ of the raw material which shows a calorific value of $3702.30 \mathrm{kcal} / \mathrm{kg}$. A large calorific value will affect the combustion process to be easier, so that the quality of bioethanol can be said to be good. From the results of the calorific value of bioethanol made from forest bananas by carrying out a simple distillation process, it still shows relatively low results, but is close to the standard value of bioethanol quality. The calorific value obtained from the results of this study is higher than the calorific value produced (Hanum et al., 2013) in durian seeds of $167.092 \mathrm{kcal} / \mathrm{kg}$.

The calorific value of the results of this study is influenced by the value of API Gravity and density. This is because the density of the fuel is expected to greatly affect the rate of fuel consumption, the greater the density is predicted to increase fuel consumption or be more wasteful (Wijaya, 2012). This means that a small density value will result in an API Gravity value and a large calorific value so that the quality of bioethanol made from bananas is declared to have good quality. Conversely, a large density value will produce an API Gravity value and a small heating value so that it will produce low quality.

\section{CONCLUSION}

Based on the results of this study, the results obtained are $24.8 \%$ ethanol content and $86 \%$ water content. This shows that the water and ethanol content of bioethanol made from forest bananas is still not up to the standards set by BSN. Bioethanol made from forest bananas has good potential to be developed because the quality of the produced bioethanol has a density value and specific gravity in accordance with the bioethanol quality standard of $0.46 \mathrm{gr} / \mathrm{mL}$ so that it has a heating value that is close to the maximum value of the bioethanol quality standard of $3702.30 . \mathrm{kcal} / \mathrm{kg}$

\section{ACKNOWLEDGMENTS}

The author would like to thank the Ministry of Research, Technology and Higher Education of the Republic of Indonesia. (Ministry of Research and Higher Education) which has provided research funds in the Beginner Lecturer Research program (PDP) 


\section{REFERENCES}

1. Adistia, N. A., Nurdiansyah, R. A., Fariko, J., Vincent, V., \& Simatupang, J. W. (2020). Potensi Energi Panas Bumi, Angin, Dan Biomassa Menjadi Energi Listrik di Indonesia. TESLA: Jurnal Teknik Elektro, 22(2), 105. https://doi.org/10.24912/tesla.v22i2.9107

2. Agustina, E., Safitri, G. I., Fatiha, I. I., Pratama, M. I., Rahmania, Safitri, R., Andiarna, F., \& Hidayati, I. (2021). Pemanfaatan Limbah Kulit Buah dan Sayur Sebagai Bahan Bakar Bioetanol. Teknik Kimia USU, 10(1), 1-6.

3. Amus, F., Arofah, K. L., Widyastuti, F. K., Chandra, A., \& Fitri, K. (2020). Perbandingan Proses SHF \& SSF dalam Produksi Bioetanol dari Bonggol Pisang Kepok. Seminar Nasional Teknologi Industri, Lingkungan Dan Infrastruktur (SENTIKUIN), 3, 9.1-9.4.

4. Badan Standar Nasional. Etanol Nabati. SNI 3565. Jakarta. 2009

5. Bestari, A., Sutrisno, Endro., \& Sumiyati, Sri. (2013) Pengaruh Lama Fermentasi Terhadap Kadar Bioetanol Dari Limbah Kulit Pisang Kepok Dan Raja. http://eprints.undip.ac.id/40888/.

6. Feri, P.H. dan Fathul. 2010. Optimasi Kondisi Operasi Pirolisis Sekam Padi Untuk Menghasilkan Bahan Bakar Briket Bioarang Sebagai Bahan Bakar Alternatif. Jurusan Teknik Kimia, Fakultas Teknik-Universitas Diponegoro.

7. Fitria, N., \& Lindasari, E. (2021). Optimasi Perolehan Bioetanol dari Kulit Nanas (Ananas cosmosus) dengan Penambahan Urea, Variasi Konsentrasi Inokulasi Starter dan Waktu Fermentasi. Jurnal Reka Lingkungan, 9(1), 1-10. https://doi.org/10.26760/rekalingkungan.v9i1.1-10

8. Hanum, F., Pohan, N., Rambe, M., Primadony, R., \& Ulyana, M. (2013). Pengaruh Massa Ragi Dan Waktu Fermentasi Terhadap Bioetanol Dari Biji Durian. Jurnal Teknik Kimia USU, 2(4), 49-54.

9. Khaidir, Setyaningsih, D., \& Haerudin, H. (2012). Dehidrasi bioetanol menggunakan zeolit alam termodifikasi. Jurnal Teknologi Indusri Pertanian, 22(1), 66-72.

10. Kurniati, Y., Khasanah, I. E., \& Firdaus, K. (2021). Kajian Pembuatan Bioetanol dari Limbah Kulit Nanas (Ananas comosus. L). Jurnal Teknik Kimia USU, 10(2), 95101.

11. Marlina, L., \& Hainun, W. N. (2020). Pembuatan Bioetanol dari Air Kelapa Melalui Fermentasi dan Destilasi-Dehidrasi Dengan Zeolit. Jurnal TEDC, 14(3), 225-260. http://poltektedc.ac.id/ejournal/index.php/tedc/article/view/425

12. Nadia, Zahratotul Firdausi ., Bayu Nugraha Samodra ., H Hargono. 2013. Pemanfaatan Pati Singkong Karet (Manihot glaziovii) Untuk produksi Bioetanol Fuel Grade Melalui Proses Distilasi-Dehidrasi Menggunakan Zeolit Alam. Semarang. Jurnal Teknologi Kimia dan Industri (Vol.2 No.3 Hal 76-81, 2013)

13. Naimah, K., \& Zen, M. R. (2021). Pengaruh Preparasi Ubi Kayu dengan Metode Bahan Baku Langsung dan Tidak Langsung terhadap Produksi Bioetanol. Journal of Science and Aplication Technology, 5(2), 325-331. https://doi.org/10.35472/jsat.v5i2.428 
14. Nugroho, R. M., \& Subagyo, R. (2020). Analisa Variasi Waktu Fermentasi Pembuatan Bioetanol Dengan Bahan Ampas Tebu Dan Kulit Pisang. Jurnal Tugas Akhir Mahasiswa Rotary, 2(2), 219-234.

15. Nurjanah, R., \& Aznury, M. (2021). Review Artikel Variasi Produksi Bioetanol dari Ampas Tebu. Jurnal Kinetika, 12(02), 64-67.

16. Retno, D. T., \& Nuri, W. (2011). Pembuatan Bioetanol dari Kulit Pisang. Prosiding Seminar Nasional Teknik Kimia "Kejuangan" Pengembangan Teknologi Kimia Untuk Pengolahan Sumber Daya Alam Indonesia, E11-1-E11-7.

17. Roni, K. A., Susanto, T., Pratama, I., \& Herawati, N. (2020). Peningkatan Kadar Bioetanol Dari Kulit Nanas Dengan Adsorben Dari Limbah Katalis Bekas Cracking Pertamina Ru Iii Plaju Yang Teraktivasi Secara Fisika. Majalah TEGI, 12(1), 29-33. https://doi.org/10.46559/tegi.v12i1.6026

18. Sulaiman, D., Romadhoni, W., \& Purnama, P. (2021). Analisis Potensi Pembangkit Listrik Tenaga Mikro Hydro Pada Anak Sungai di Bulungan. Jurnal Kumparan Fisika, 4(1), 61-66. https://doi.org/10.33369/jkf.4.1.61-66

19. Sulistyaningsih, L. D., \& Wawo, A. H. (2011). Kajian Etnobotani Pisang-pisang Liar (Musa spp.) Di Malinau, Kalimantan Timur. Biosfera, 28(1), 43-47.

20. Wijaya, I Made A S., Arthawan, I Gusti K A., \& Sari, Anis N. (2012). Potensi Nira Kelapa Sebagai Bahan Baku Bioetanol. Jurnal Bumi Lestari, Vol 12 No.1,pp 85 - 92.

21. Wusnah, W., Bahri, S., \& Hartono, D. (2019). Proses Pembuatan Bioetanol dari Kulit Pisang Kepok (Musa acuminata B.C) secara Fermentasi. Jurnal Teknologi Kimia Unimal, 8(1), 48. https://doi.org/10.29103/jtku.v8i1.1915.

22. Alshammari, A. M., Adnan, F. M. A., Mustafa, H., \& Hammad, N. (2011). Bioethanol fuel production from rotten banana as an environmental waste management and sustainable energy. African Journal of Microbiology Research, 5(6), 586-598. https://doi.org/10.5897/AJMR10.231 